\title{
Effects of Magnesia Incorporation on Properties of Polystyrene/Magnesia Composites
}

\author{
Salah Eddine Hachani, ${ }^{1, \star}$ Abdulmounem Alchekh wis, ${ }^{2}$ Zelikha Necira, ${ }^{1}$ \\ Nadia Nebbache, ${ }^{1}$ Ahmed Meghezzi ${ }^{1}$ and Guralp Ozkoc ${ }^{2}$ \\ ${ }^{1}$ Laboratory of Applied Chemistry, Mohamed Khider University, Biskra 07000, Algeria. \\ ${ }^{2}$ Department of Chemical Engineering, Kocaeli University, Kocaeli 41380, Turkey. \\ *Corresponding author: E-mail: salaho_hachani@yahoo.fr \\ Phone number: +213791162887
}

Received: 02-03-2018

\begin{abstract}
In the present study, the effects of magnesia particles on thermal, dynamic mechanical, morphological, and surface properties of polystyrene resin are investigated. In general, the addition of magnesia particles in polystyrene matrix increases the thermal stability, storage modulus, and wettability, on other hand does not affect the molecular mobility. SEM results showed a limited distribution of magnesia particles in the polystyrene matrix at $15 \mathrm{wt} . \%$.
\end{abstract}

Keywords: Magnesia; polystyrene; Thermal stability; Storage modulus; Wettability; Molecular mobility.

\section{Introduction}

Thermoplastic polymers are largely used due to their attractive advantages such as recyclability, low process temperature, and low cost. ${ }^{1}$ Polystyrene (PS) is one of the most important thermoplastics used today and produced in a huge amount worldwide. This resin has been extensively applied in many fields such as computer industry, foam packaging, toys, and cell-culture wares ${ }^{2,3}$ due to its high modulus, satisfactory tensile strength, transparency, and its low cost. ${ }^{2}$

The polymers are rarely used in the pure form because of their poor properties; they must be combined with other materials in the form of fibers, particles, and spheres considered as reinforcement, which leads to generate new materials having improved properties, namely polymer composites. ${ }^{4}$ The improvement of polystyrene properties have received great attention from both academia and industry; studies have been conducted in this context including minerals, ${ }^{5}$ glass fibers, ${ }^{6}$ boron nitride, ${ }^{7}$ and nanoparticles such as carbon nanotubes. ${ }^{8}$

Two basic techniques to prepare the PS composites are well known. In solvent casting technique, PS is dissolved in a solvent, such as toluene, and then the filler particles are mixed into solution by means of mechanical or ultrasonic mixing. After casting this solution over a surface, solvent is evaporated and the composite PS film is obtained. ${ }^{9}$ The other technique is the melt-compounding of PS composites. In this technique, PS is transferred to viscous-melt by heat in an extruder or an internal mixer. Thanks to the shear forces exerted in these devices, the filler particles can be uniformly dispersed in the matrix. ${ }^{10}$

Thermoplastic polymers filled with metal oxides are widely used in sensors, ${ }^{11}$ gas membranes, ${ }^{12}$ electronic devices, ${ }^{13}$ optoelectronics, and organic photovoltaic. ${ }^{14}$ Magnesia $(\mathrm{MgO})$ is an interesting metal oxide characterized by excellent thermodynamic stability, low dielectric constant, low refractive index, and very large band gap. This metal oxide is largely used in catalysis, refractory, ceramic industry, and toxic waste treatment. ${ }^{15}$ Magnesia can be elaborated using different methods such as a combustion process, ${ }^{16}$ chemical vapour deposition technique, ${ }^{17}$ and ultrasound assisted one pot method. ${ }^{18}$

Few studies have treated the use of magnesia in the field of polymer engineering. In a study, it was found that carboxylated nitrile rubbers reinforced with magnesia exhibit better physical properties compared to the ones reinforced with other metallic oxides. ${ }^{19}$ Another study demonstrated that the mechanical properties of unsaturated polyester resin have increased after magnesia incorporation. ${ }^{20} \mathrm{~A}$ significant improvement of thermal stability of poly (ethylene terephthalate) has achieved at high magnesia amount. ${ }^{21}$ To the best of our knowledge no experimen- 
tal background has been proposed to study the effects of magnesia in properties of polystyrene matrix.

The present contribution aims to study the feasibility of magnesia incorporation in the improvement of polystyrene resin properties. Both neat polystyrene and magnesia filled polystyrene composite films prepared by melt-compounding using a single screw extruder have been tested by several techniques to investigate the effects of magnesia on thermal, morphological, dynamic mechanical properties, and wettability of polystyrene matrix.

\section{Experimental Part}

\section{1. Materials}

The polystyrene used in the current study was provided by Spanish Petrochemicals Company. Highly pure magnesia powder with an average particle size of $0.447 \mu \mathrm{m}$ was purchased from BIOCHEM Chemopharma. The polystyrene platelets were grinded using a commercial laboratory milling to ease the mixing between the polystyrene and the magnesia powder during the melt-compounding process.

\section{2. Film Preparation}

Polystyrene/Magnesia composite films were obtained by extrusion. Both polystyrene and magnesia powders were mixed using a commercial mixer during 5 minutes at room temperature. The resulting mixture was extruded using Plasti-Corder PLE 330 single screw extruder. The extrusion conditions were a barrel temperature of $180{ }^{\circ} \mathrm{C}$ and a screw speed of 27 r.p.m. The magnesia loadings were 5,10 , and $15 \%$ by weight.

\subsection{Characterisation}

\section{3. 1. DSC Analysis}

DSC measurements were carried out using a calorimeter model Mettler Toledo. Samples of 5-6 mg were scanned from 30 to $140{ }^{\circ} \mathrm{C}$ under nitrogen atmosphere at heating rate of $10^{\circ} \mathrm{C} / \mathrm{min}$.

\section{3. 2. DMA Analysis}

Dynamic mechanical analysis (DMA) was performed using DMA Metravib $50 \mathrm{db}$ machine operating at frequency of $1 \mathrm{~Hz}$. Samples of rectangular form were put in tensile mode, both storage modulus and loss modulus were measured in the temperature range from 40 to $150^{\circ} \mathrm{C}$ at a heating rate of $10^{\circ} \mathrm{C} / \mathrm{min}$.

\section{3. 3. Contact Angle Measurement}

To measure the contact angle, the photograph of the droplet of distilled water put on the surface of the poly- meric material was taken by a digital camera. The contact angles were measured on digital photographs using image analysis software (Image J).

\section{3. 4. Thermogravimetric Analysis}

Thermogravimetric analysis (TGA) was conducted using TGA/DTA Mettler Toledo analyser. Samples of 5-6 mg were heated from 30 to $580^{\circ} \mathrm{C}$ under air atmosphere at heating rate of $10^{\circ} \mathrm{C} / \mathrm{min}$.

\section{3. 5. Scanning Electron Microscopy (SEM)}

Magnesia particles distribution in PS matrix and fractured surface topology were investigated by scanning electron microscopy (SEM) (JEOL JSM-6335F). Samples were coated with gold prior to analysis.

\section{Results and Discussions}

\section{1. DSC Results}

Both pure polystyrene and its magnesia filled composites was the subject of differential scanning calorimetric analysis to investigate polystyrene molecular mobility variations after magnesia incorporation. DSC curves of different samples under probe are shown in Figure 1. DSC thermogram of pure polystyrene exhibits only one thermal event, the glass transition temperature Tg; the temperature at which a polymer transforms from a glassy to a rubbery state. $\mathrm{Tg}$ has been determined as the value corresponding to inflection point of onset and end-set temperature profiles. For the neat polystyrene and polystyrene filled with 5 , 10 , and 15 wt.\% of magnesia, $\mathrm{Tg}$ values are $95.56,94.84$, 95.61 , and $95.12{ }^{\circ} \mathrm{C}$, respectively. This indicates that incor-

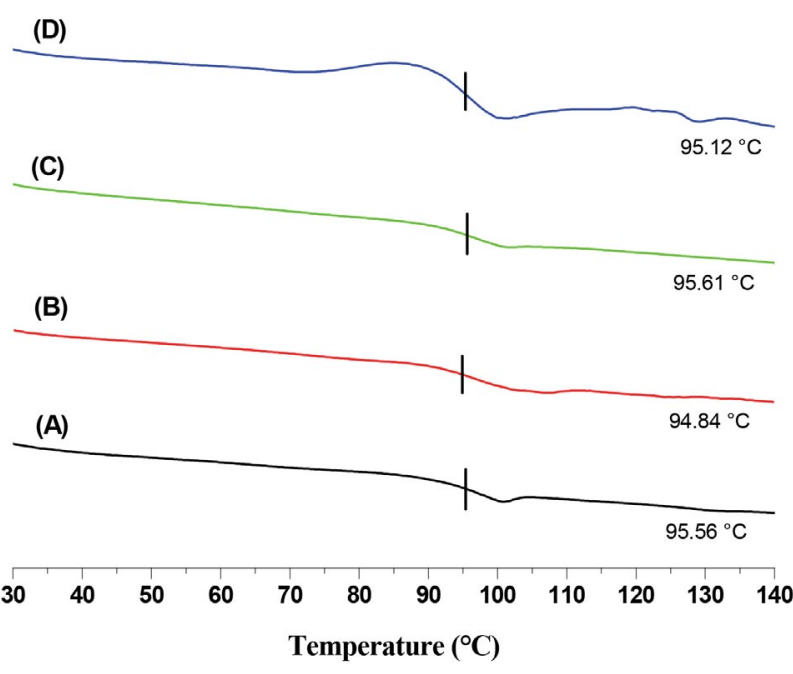

Figure 1: DSC thermograms of (A) neat PS, (B) 5 wt.\% magnesia reinforced PS, (C) $10 \%$.wt magnesia reinforced PS, and (D) 15 wt.\% magnesia reinforced PS. 
poration of magnesia particles does not affect the glass transition temperature $\mathrm{Tg}$ of polystyrene matrix. This experimental finding could be attributed to the weak interactions between magnesia particles and polystyrene matrix, the polystyrene molecular mobility is not modified and no significant variations in glass transition temperature can be registered.

\section{2. DMA Results}

Dynamic mechanical analysis (DMA) was used to study the effect of magnesia incorporation on thermo-mechanical properties of polystyrene matrix. The temperature dependence of storage modulus (E') of polystyrene and its magnesia composites is shown in Figure 2. It can be seen that addition of magnesia particles enhanced the storage modulus of the studied composites in the temperature range from 40 to $85^{\circ} \mathrm{C}$, as an example the storage modulus at $60{ }^{\circ} \mathrm{C}$ of neat polystyrene increased by $17 \%$ with the addition of $15 \mathrm{wt} . \%$ of magnesia. This increase in storage modulus could be attributed to the increase in the stiffness of polystyrene matrix due the reinforcement effect of magnesia particles. Suzhu Yu et al. also have reported amelioration in storage modulus of the neat polystyrene after aluminium powder addition. $^{22}$

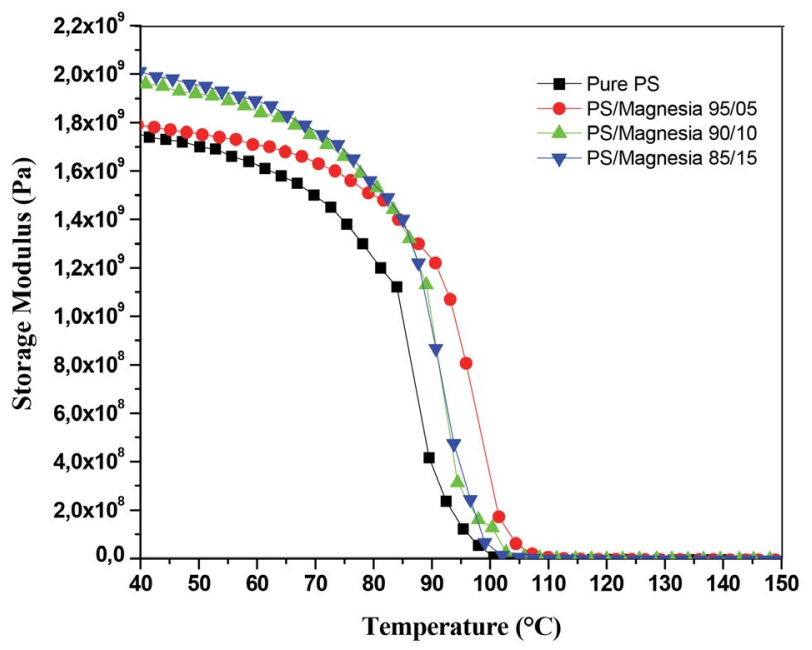

Figure 2: Storage modulus variations of pure PS and PS/Magnesia composites.

Loss modulus curve can be used to determine the glass transition temperature $\mathrm{Tg}$ for each studied formulation using the peak maximum in loss modulus and its temperature dependence. Loss modulus variations of neat polystyrene and its magnesia filled composites as a function of temperature are shown in Figure 3. It is evident that the addition of magnesia particles has not a remarkable effect on the glass transition temperature $\mathrm{Tg}$ of polystyrene matrix.

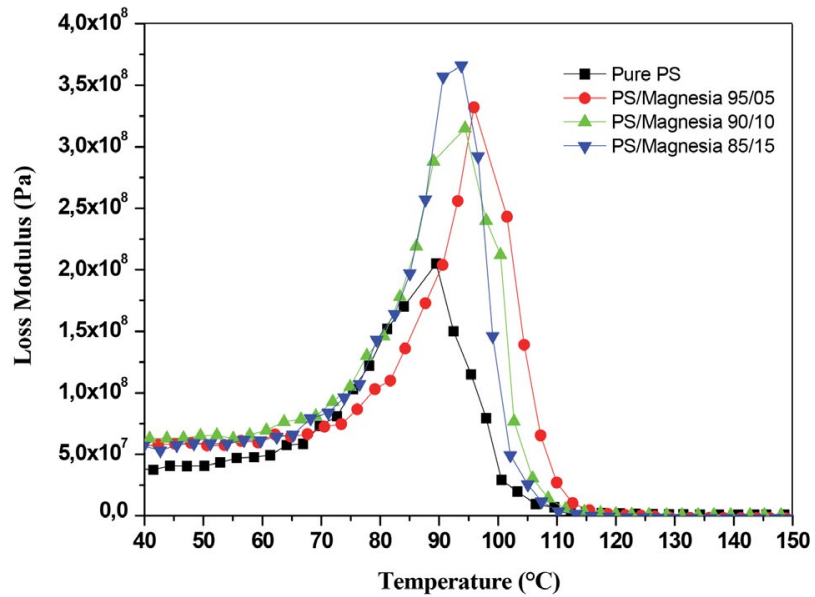

Figure 3: Loss modulus variations of pure PS and PS/Magnesia composites.

\section{3. Contact Angle Measurements Results}

Contact angle measurement is a fundamental method used in many scientific and industrial fields such as surface chemistry and biomaterials. Contact angle measurements can inform about surface properties such as surface energy, wettability, and surface modification. ${ }^{23}$ In the current study, we adopt this technique to investigate the polystyrene surface wettability which is considered as a key factor to find an appropriate application for a polymer film. Figure 4 shows the appearance of water drops on the
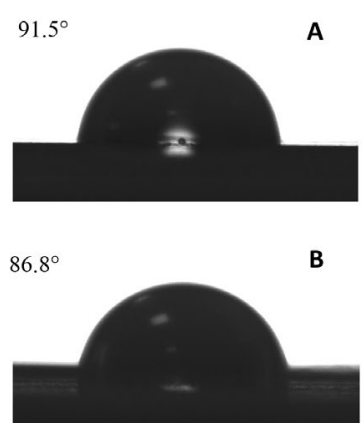

Figure 4: Water contact angles of (A) PS, (B) PS/5 wt.\% Magnesia reinforced composite, (C) PS/10 wt.\% Magnesia reinforced composite, and (D) PS/15 wt.\% Magnesia reinforced composite. samples indicating the water contact angles. The pure polystyrene has a hydrophobic surface with an average water contact angle of $91.5^{\circ}$. The insertion of 5, 10, and 15 wt. $\%$ of magnesia particles in polystyrene matrix decreased significantly the water contact angle to $86.8,82.1$, and $75.5^{\circ}$, respectively. The presence of magnesia in polystyrene composite films tends to reduce the interfacial tension between water and polystyrene interface, which makes the polystyrene surface hydrophilic. 


\section{4. Thermogravimetric Analysis (TGA) Results}

Thermogravimetric analysis (TGA) was conducted to investigate thermal stability of polystyrene matrix after magnesia incorporation. TGA and DTG thermograms of neat polystyrene and its composites containing 5,10 , and $15 \mathrm{wt} . \%$ of magnesia are shown in Figure 5 and 6. Thermal degradation parameters of pure polystyrene and its magnesia composites were extracted from TGA and DTG curves and presented in Table 1. Single phase degradation is observed for the pure polystyrene; this phase is attributed to the decomposition of polystyrene matrix to volatile styrene monomers where mass loss reaches $98 \%$ at $570{ }^{\circ} \mathrm{C}$. When $15 \mathrm{wt} . \%$ of magnesia powder added as filler, the thermal stability of the composites under study is ameliorated, where $\mathrm{T}_{\max }$ increased from 426.9 to $432.8^{\circ} \mathrm{C}$ and the final residue increased from 1.6 to $16.6 \%$, indicating that magnesia has a retardation effect on the heat transfer in the polystyrene matrix during thermal degradation. On other hand, it can be seen that PS/magnesia 95/05 sample shows the highest IDT value compared with the other formulations, this could be attributed to the good quality of magnesia dispersion and distribution into polystyrene matrix.

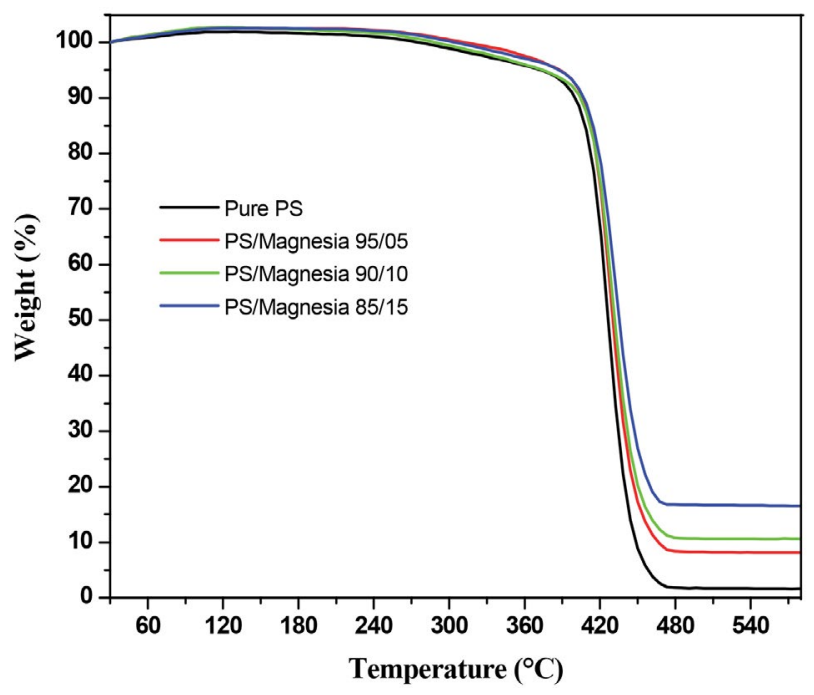

Figure 5: TGA curves of neat polystyrene and PS/Magnesia composites

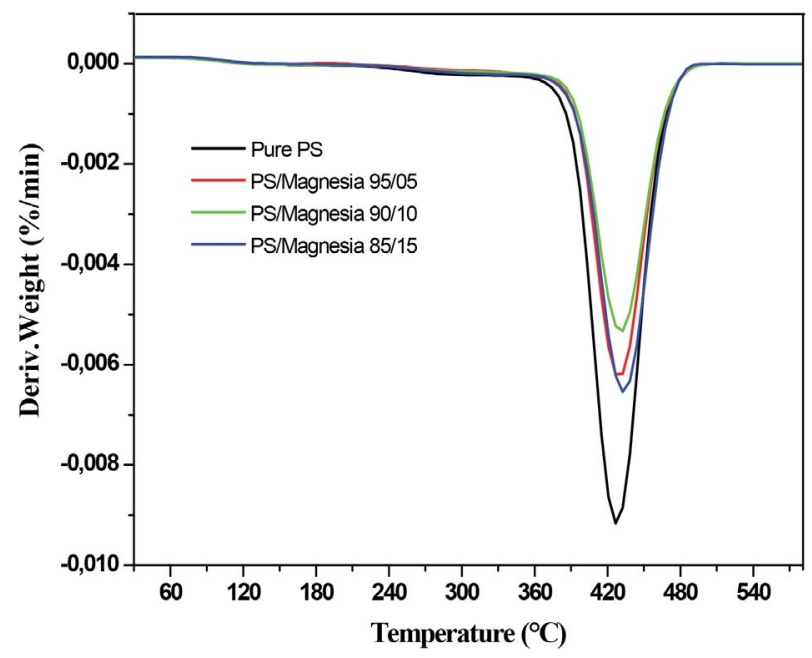

Figure 6: DTG curves of neat polystyrene and PS/Magnesia composites.

\section{5. Morphology of PS/Magnesia Composites}

Filler dispersion and distribution in the hosting polymer matrix are two essential parameters which can strongly influence the final properties of the elaborated composite materials. Filler dispersion represents the agglomeration level of filler particles in the polymer matrix whereas filler distribution is filler homogeneity in the resin matrix. Good dispersion and distribution of filler particles in the hosting polymer matrix is desired for maximum properties enhancement. SEM images of selected PS/Magnesia composite samples at different magnifications are shown in Figure 7. SEM images of sample containing $10 \mathrm{wt} . \%$ of filler show homogeneous distribution of magnesia particles in polystyrene matrix. In the case of sample containing $15 \mathrm{wt} . \%$ of filler, the presence of agglomerations in white colour indicates a difficult dispersion of magnesia particles in polystyrene matrix during the elaboration process.

\section{Conclusion}

PS/Magnesia composites were investigated as function of magnesia loading level. It is found that magnesia particles are difficult to distributed at $15 \mathrm{wt} . \%$. DSC results

Table 1: Thermal degradation parameters of pure polystyrene and PS/Magnesia composites.

\begin{tabular}{ccccccc}
\hline Formulation & IDT $\left({ }^{\circ} \mathbf{C}\right)$ & $\mathbf{T}_{\text {max }}\left({ }^{\circ} \mathbf{C}\right)$ & $\mathbf{T}_{\mathbf{2 0} \%}\left({ }^{\circ} \mathbf{C}\right)$ & $\mathbf{T}_{\mathbf{5 0 \%}}\left({ }^{\circ} \mathbf{C}\right)$ & $\mathbf{T}_{\mathbf{7 5 \%}}\left({ }^{\circ} \mathbf{C}\right)$ & Residue $^{(\%)}$ \\
\hline Pure PS & 372.3 & 426.9 & 412.4 & 426.7 & 437.1 \\
PS/Magnesia 95/05 & 388.2 & 428.9 & 416.1 & 430.4 & 442.6 & 01.6 \\
PS/Magnesia 90/10 & 374.8 & 430.9 & 416.5 & 432.0 & 445.4 & 08.0 \\
PS/Magnesia 85/15 & 387.3 & 432.8 & 419.0 & 435.5 & 452.2 & 10.6 \\
\hline
\end{tabular}

IDT: initial decomposition temperature: the temperature at $5 \%$ of mass $\operatorname{loss}^{24} \mathbf{T}_{\max }$ : the temperature where the maximum weight loss rate occurred, this temperature is determined from DTG thermogram. $\mathbf{T}_{\mathbf{2 0} \%}$ : the temperature at $20 \%$ of mass loss. $\mathbf{T}_{\mathbf{5 0} \%}$ : the temperature at $50 \%$ of mass loss. $\mathbf{T}_{75 \%}$ : the temperature at $75 \%$ of mass loss. Residue: the final amount after the end of the heating. 


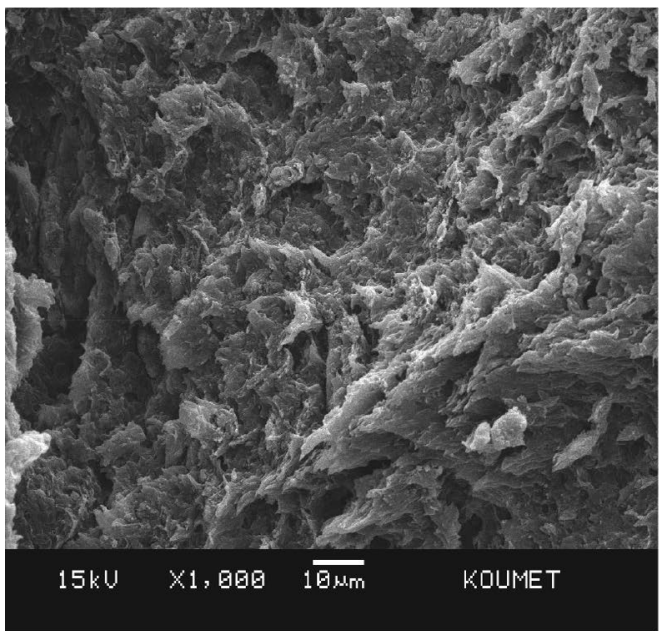

(A) $10 \mathrm{wt} . \%$ of mangesia

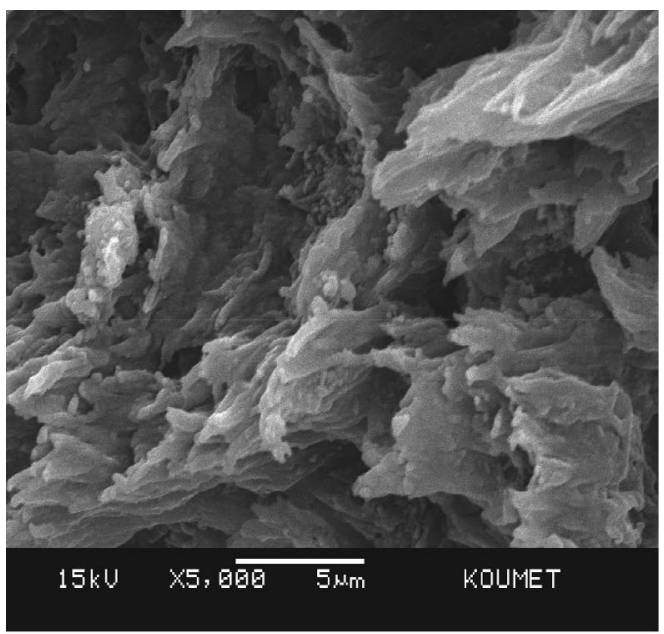

(C) 10 wt.\% of mangesia

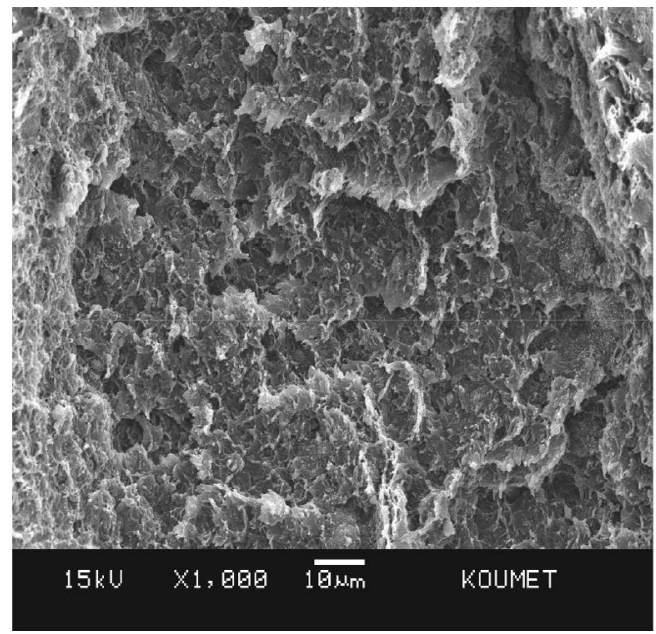

(B) 15 wt.\% of mangesia

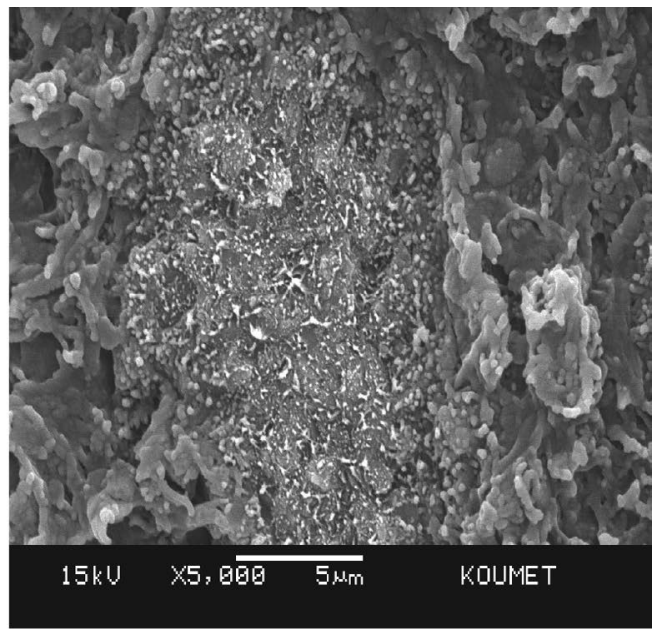

(D) 15 wt.\% of mangesia

Figure 7: SEM micrographs of PS/Magnesia composites with respect to magnesia loading level (Magnification; $\times 1000, \times 5000$ ).

revealed that the glass transition temperature $\mathrm{Tg}$ of polystyrene matrix was not affected by filler addition. Thermal degradation data showed that the incorporation of magnesia particles has a positive effect on thermal stability of the composites under investigation where $\mathrm{T}_{\max }$ increased from 426.9 to $432.8^{\circ} \mathrm{C}$ and the final residue increased from 1.6 to $16.6 \%$. DMA results showed that storage modulus increased after introducing magnesia particles. Contact angle measurements indicated that the presence of magnesia particles changed the nature of polystyrene surface from hydrophobic to hydrophilic where the average contact angle decreased from 91.5 to $75.5^{\circ}$ after 15 wt.\%.

\section{References:}

1. L. Peng, Y. Deng, P. Yiand, X. Lai, Micromech.Microeng. 2014, 24, 1-8. DOI:10.1088/0960-1317/24/1/013001
2. E. Youcef, R. Haddad, SpringerPlus. 2013, 2, 1-32. DOI:10.1186/2193-1801-2-1

3. J. A. Chinn, T. A. Horbett, B. D. Ratner, Journal of Tissue Culture Methods. 1994, 16, 155-159.

DOI: $10.1007 / \mathrm{BF} 01540643$

4. R. C. Thompson, C. J. Moore, F. S. V. Saal, S. H. Swan, Philos Trans R Soc Lond B Biol Sci. 2009, 364, 2153-2166.

DOI:10.1098/rstb.2009.0053

5. S. E. Hachani, A. Meghezzi, M. Slimani, N. Nebbache, Int. J. Chem. Sci. 2016, 14, 1236-1242.

6. Q. Zhu, F. Wu, Q. Yang, J. Wang, W. Chen, Journal of Wuhan University of Technology-Mater. Sci. Ed. 2010, 25, 780-784.

7. K. Kinoshita, N. Matsunaga, M. Hiraoka, H. Yanagimoto, H. Minami, RSC Adv., 2014, 4, 8605-8611.

8. Y. Jia, Z. Jiang, J. Peng, X. Gong, Z. Zhang, Composites Part A. 2012, 43, 1561-1568.

DOI:10.1016/j.compositesa.2012.04.011

9. O. Bera, B. Pili, J. Pavličević, M. Jovičić, B. Holló, K. Mészáros 
Szécsényi, M. Špirkova, Thermochimica Acta. 2011, 515, 1-5. DOI:10.1016/j.tca.2010.12.006

10. S. P. Thomas, S. Thomas, R. Abraham, S. Bandyopadhyay, eXPRESS Polymer Letters. 2008, 2, 528-538.

DOI:10.3144/expresspolymlett.2008.63

11. N. Donato, D. Aloisio, M. Latino, A. Bonavita, D. Spadaro, G. Neri, Sensors and Microsystems. 2012, 109, 67-71. DOI:10.1007/978-1-4614-0935-9_12

12. A. Michas, P. Millet, Journal of Membrane Science. 1991, 61, 157-165. DOI:10.1016/0376-7388(91)80012-U

13. A. Malik, A. Sêco, E. Fortunato, R. Martins, Journal of Non-Crystalline Solids. 1998, 227-230, 1092-1095.

DOI:10.1016/S0022-3093(98)00248-8

14. O. Pachoumi, C. Li, Y. Vaynzof, K. K. Banger, H. Sirringhaus, Advanced Energy Materials. 2013, 3, 1428-1436.

DOI:10.1002/aenm.201300308

15. R. Kumar, A. Sharma, N. Kishore, International Journal of Engineering, Applied and Management Sciences Paradigms. 2013, 7, 66-70.

16. F. Gu, C.Z. Li, H.B. Jiang, J. Cryst. Grow. 2006, 289, 400-404. DOI:10.1016/j.jcrysgro.2005.11.116

17. H. Saitoh, Y. Okada, S. Ohshio, J. Mater. Sci. 2002, 37, 45974602. DOI:10.1023/A:1020696215411
18. S. Gandhi, P. Abiramipriya, N. Pooja, J. Juliat, L. Jeyakumari, A. Y. Arasi, V. Dhanalakshmi, M. R. G. Nair, R. Anbarasan, Journal of Non-Crystalline Solids. 2011, 357, 181-185.

DOI:10.1016/j.jnoncrysol.2010.09.050

19. L. Ibarra, M. Alzorriz, Journal of Applied Polymer Science. 2007, 103, 1894-1899. DOI:10.1002/app.25411

20. J. Przepiorski, J. Karolczyk, T. Tsumura, M. Toyoda, M. Inagaki, A. W. Morawski, J Therm Anal Calorim. 2012, 107, 1147-1154. DOI:10.1007/s10973-011-1910-1

21. J. Wang, L. Fan, S. Xu, M. Zeng, Q. Liu, Acta Materiae Compositae Sinica. 2011, 28, 65-70.

22. S. Yu, P. Hing, Journal of Applied Polymer Science. 2000, 78, 1348-1353.

DOI:10.1002/1097-4628(20001114)78:7<1348::AID-APP50 $>3.0 . \mathrm{CO} ; 2-\mathrm{V}$

23. G. Lamour, A. Hamraoui, A, Buvailo, Y. Xing, S. Keuleyan, V. Prakash, A. Eftekhari-Bafrooei, E. Borguet, Journal of Chemical Education. 2010, 87, 1403-1407.

DOI:10.1021/ed100468u

24. M. Worzakowska, J Therm Anal Calorim.2015, 121, 235-243. DOI:10.1007/s10973-015-4547-7

\section{Povzetek}

$\mathrm{V}$ tej študiji smo raziskovali učinke delcev $\mathrm{MgO}$ na termične, mehanske, morfološke in površinske lastnosti polistirenske smole. Na splošno dodajanje delcev $\mathrm{MgO}$ v polistirenski matriks poveča toplotno stabilnost, modul shranjevanja in omočljivost, na drugi strani pa ne vpliva na molekularno mobilnost. Rezultati vrstične elektronske mikroskopije (SEM) so pokazali omejeno porazdelitev delcev $\mathrm{MgO}$ v polistirenskem matriksu (masni odstotek $\mathrm{MgO}=15 \%$ ). 